\title{
A Study on Service Quality Perspectives and Customer Satisfaction in New Private Sector Banks
}

\author{
${ }^{1}$ Dr. N. Ragavan, ${ }^{2}$ Dr. R.Mageh \\ ${ }^{1}$ Assistant Professor, Department of Commerce, University of Madras, Chennai - 600 005, India. \\ ${ }^{2}$ Associate Professor, Department of Management Studies, Anna University, Chennai-600 025, India.
}

\begin{abstract}
The main objective of this study is to examine the influence of service quality dimensions on customer overall satisfaction. This study posits and develops an instrument of service quality and examines the relationship between perceived service quality dimensions and customer overall satisfaction. The results shows that the most important service quality practice on customer satisfaction is responsiveness as it is perceived as a dominant service quality. The results reveal that the service quality dimensions of tangibles, responsiveness, reliability and assurance are positively and significantly influencing the customers overall satisfaction, while the empathy is negatively and significantly influencing the customers overall satisfaction. Thus, this present research concluded that service quality is the basic and also most important factor that influences the overall customer satisfaction. This finding reinforces the need for banks managers to place an emphasis on the underlying dimensions of service quality especially on responsiveness and should start with improving service quality in order to raise overall customer satisfaction.
\end{abstract}

Key Words: Customer Satisfaction, New Private Sector Banks, Service Quality.

\section{Introduction}

Service quality is a recent and more dynamic decisive issue in the marketing thought. It also helps control the competitive position and consequently determines the market share and profits (Shabib, 2002). Therefore, the ability of banks to continue and survive in the market depends on their ability to respond to the requirements of change and interact with the output of it. As the customers' needs and wishes are shaped and formed in the light of their economic, social and civilisation conditions, there is a close relationship between the banks' ability to continue and survive and their ability to produce services that fit in with the increasing and changing needs of the customers. Hence, service organizations, especially banks, work hard to find effective ways to counter external changes in order to survive and they enhance their effectiveness by means of activating their services and creating and developing new ones. Thus, The importance of achieving high levels of quality lies in the number of economic and non-economic benefits resulting from quality commitment and lies in eliminating its problems and the causes of these problems.

Customer satisfaction is a measure of extent the existing bank is fulfilling the general expectations of a customer and how far and/or close does the existing bank come to the customer's ideal bank in his mind (Beerli, et. al., 2004). Customer satisfaction can be viewed as the future intentions of customers towards the service provider, which is more or less related to the attitude. Customers perceive services in terms of the quality of the service and how satisfied they are overall with their experiences (Zeithaml and Bitner, 2003). Satisfaction is the consumer's fulfilment response (Oliver, 1997). Customer satisfaction is influenced by price, product quality; service quality and brand image (Wirtz, et.al., 2000). Recently, there has been a keen interest, especially in banking, where banks are looking at the life time value of the customer base rather than focusing on the cost of transactions.

With the entry of new generation tech-savvy private banks, the banking sector has become too competitive. To deal with the emerging situations, bankers have to shed a lot of old ideas, change in practices, develop customer loyalty programmes and adopt a distinct approach to meet the challenges ahead. In a fiercely competitive market, non-price factors like customer service become more important (Kotler, 2003). Hence, it is desirable for new private banks to develop a customer-centric approach for future survival and growth. The awareness has already dawn that prompt, efficient and speedy customer service alone will tempt the existing customers to continue and induce new customers to try the services offered by a new private bank. With this background, the present research is attempted to study the service quality perspectives and customer satisfaction in new private sector banks in Chennai. 


\subsection{Service Quality}

\section{Literature Review}

Karim and Cowling (1996) defined quality as anything that accorded with the characteristics of the product to meet the external clients' needs. In addition, the product quality differed from that of a service as the earlier was tangible, whereas the latter was intangible. The American Society for Marketing defined service as activities or benefits that were offered for sale or that were offered for being related to a particular product.

Service quality as perceived by customers definitely indicated what was left of their previous perception of the service quality and the level of their satisfaction with the current performance of the service. This meant that satisfaction was an intermediary factor between the previous perceptions of the service quality and the present perception of it. Accordingly, and within this general framework customers could assess the service actual quality provided to them (Mualla and Deeb, 1998). Hence, the customer's satisfaction with the actual performance level of service had a further impact on the formation of the customers' perceptions of service quality. And one the service was purchased again, satisfaction becomes a major approach to the process of assessing service quality (Mualla and Deeb, 1998).

Service quality scale proposed by the Parasuraman, et. al., (1985) had been reasonably used by the academicians and managers (Parasuraman, et. al., 1991; Cronin and Taylor, 1992; Babakus and Boller, 1992; Carman, 1990). Zeithaml (1987) explained the service quality as "Service quality is the consumer's judgment about an entity's overall excellence or superiority. It is a form of attitude, and results from a comparison of expectations to perceptions of performance received".

Angur, et. al., (1999) examined the applicability of alternative service quality measure in the Retail Banking industry in India. They conducted their research on the consumers of two major banks in India. They used SERVQUAL model to measure the overall service quality. They found that all the dimensions were not equally important in explaining variance in overall service quality. The result indicated that responsiveness and reliability seem to be the most important dimensions followed by the empathy and tangible dimensions; whereas, assurance appeared to be the least important dimension. Finally, they concluded that SERVQUAL was the best measure of service quality in banking industry.

Bahia and Nantel (2000) conducted a research to develop a valid measurement of perceived service quality in the Retail Banking sector in Canada. They argued that the SERVQUAL approach had not except from critics; therefore, they developed a new measurement for perceived service quality in Retail Banking. They proposed a scale that was called Bank Service Quality (BSQ). It comprised 31 items classified across six dimensions as: effectiveness and assurance, access, price, tangibles, range of services offered and accuracy and reliability.

Kotler (2003) defined service as any behaviour or act based on a contact between two parties: the provider and the receiver and the essence of this reciprocal process in intangible. Michael (2003) defined service as a set of characteristics and overall properties of the service which aimed to satisfy the clients and meet their needs.

Huseyin, et. al., (2005) believed that good knowledge of the characteristics and advantages of service quality on the part of banks did contribute for their success and their persistence in the international banking competitive environment. Thus, the quality of banking service was an integrative assessment of the services offered to the external client, for clients were considered to be independent individuals with various requirements on the basis of which services were provided, based on certain specification.

Karatepe, et. al., (2005) demonstrated that the customers of retail banks with favourable perceptions of service quality had higher satisfaction. Another study conducted by Al-Hawari and Ward (2006) on banking sector and argued that “...the positive effects exerted by e-service quality on customers' satisfaction while these effects increase the bank's benefits". Although there were empirical studies which demonstrated that customer satisfaction completely mediated the relationship of service quality and loyalty (Ibánez, et. al., 2006; Lanka, et. al., 2009).

Hossain and Leo (2009) emphasised that banks had to care about the quality of their services since this quality was considered the essence or core of strategic competition. Bei and Chiao (2006) found the consequence of perceived service quality on loyalty and satisfaction between the Taiwanese bank customers. Such results were also reported for the customers of retail banks in Iran (Mosahab, et. al., 2010). Malik, et. al., (2011) concluded that not all SERVQUAL dimensions had their role in boosting the satisfaction level of the banking clients. It was interesting to note that assurance posted relatively higher contribution in satisfying the clients than did reliability.

\subsection{Customer Satisfaction}

Satisfaction became a popular topic in marketing during the 1980s and was debated topic during both business expansions and recessions. Most discussions on customer satisfaction involved customer expectation of the service delivery, actual delivery of the customer experience and expectations that were either exceeded or 
unmet. If expectations were exceeded, positive disconfirmation resulted, while a negative disconfirmation resulted when customer experience was poorer than expected. In today's world of intense competition, the key to sustainable competitive advantage lied in delivering high quality service that would in turn result in satisfied customers(Shemwell,1998).

Levesque and McDougall (1996) concluded that competitive interest rate was one of the important determinants of customer satisfaction in retail banking sector. They found that a good "employee-customer" relationship can increase the satisfaction level. They pointed out that problem-recovery was important to maintain the customer satisfaction. However, the results did not confirm that satisfactory problem-recovery can increase satisfaction. Finally, they concluded that competitiveness and convenience of the banks were the two important determinants of customer satisfaction

Oliver (1997) defined satisfaction as "the consumer's fulfillment response", a post consumption judgment by the consumer that a service provided a pleasing level of consumption-related fulfillment, including under or over-fulfillment. Huang (1998) also defined five factors used to evaluate customer satisfaction: product, service, staff, overall performance of products and closeness to expectation. Kolter and Armstrong (1999) defended the customer satisfaction as the customer's perception that compared their pre-purchase expectations with post purchase perception.

Customer satisfaction was the customers' evaluation of services after purchase as opposed to their expectation (Oliver, 1997; Zeithaml and Bitner, 2000). Baker and Crompton (2000) defended satisfaction as a personal experience and mentality related the nitration between personal expectation and actual receive. Customer satisfaction was the overall evaluation to services. It was the reflection customers make to their previous purchase.

Devlin (2001) pointed out that "customers perceive very little difference in the services offered by retail banks and any new offering is quickly matched by competitors." Jamal and Naser (2003) found that relational and core features of bank's quality of service appeared to be linked to customer satisfaction. The perspective proposes that satisfied customers made favourable quality judgments about services, because such customers' judge things in higher quality due to positive affect they have experienced (Gilbert, et. al., 2004).

Karatepe, et. al., (2005) demonstrated that the customers of retail banks with favourable perceptions of service quality had higher satisfaction. Arasli, et. al., (2005) pointed out that reliability dimension of SERVQUAL had the highest impact on customer satisfaction in Greek Cypriot banking industry, whereas reliability was not related to customer satisfaction, found by Chaniotakis and Lymperopoulos (2009). Although there are empirical studies which demonstrated that customer satisfaction completely mediates the relationship of service quality and loyalty (Ibánez. et. al., 2006; Lanka, et. al., 2009).

Abu-Mu'amar (2005) found a strong, statistically significant relation between the customer's satisfaction and the banking service quality provided. He also concluded that the customers' continuation in dealing with banks and being more loyal to these banks basically depended on their assessment of the service quality provided. He also indicated the necessity to understand the client's expectations in order to provide a better banking service to them and made them feel satisfied.

Awwad (2006) noted that there was a set of dimensions that influenced customers' satisfaction such as care, credibility, assurance and security. The more credibility customers had in the service and its speed and accuracy, the more satisfied they would get. Mengi (2009) found that responsiveness and assurance were important factor for customer satisfaction whereas, Kumar, et. al., (2010) found that assurance, empathy and tangibles were the important factor and on the other hand Ahmed, et. al., (2010) found out that empathy was negatively related to customer satisfaction. Mohammad and Alhamadani (2011) found that tangibles, reliability, responsiveness, assurance and empathy had significant influence on customer satisfaction and also concluded that the service quality was an important antecedent of customer satisfaction. 


\section{Model And Hypothesis}

The model and hypothesis for the present study is as follows:

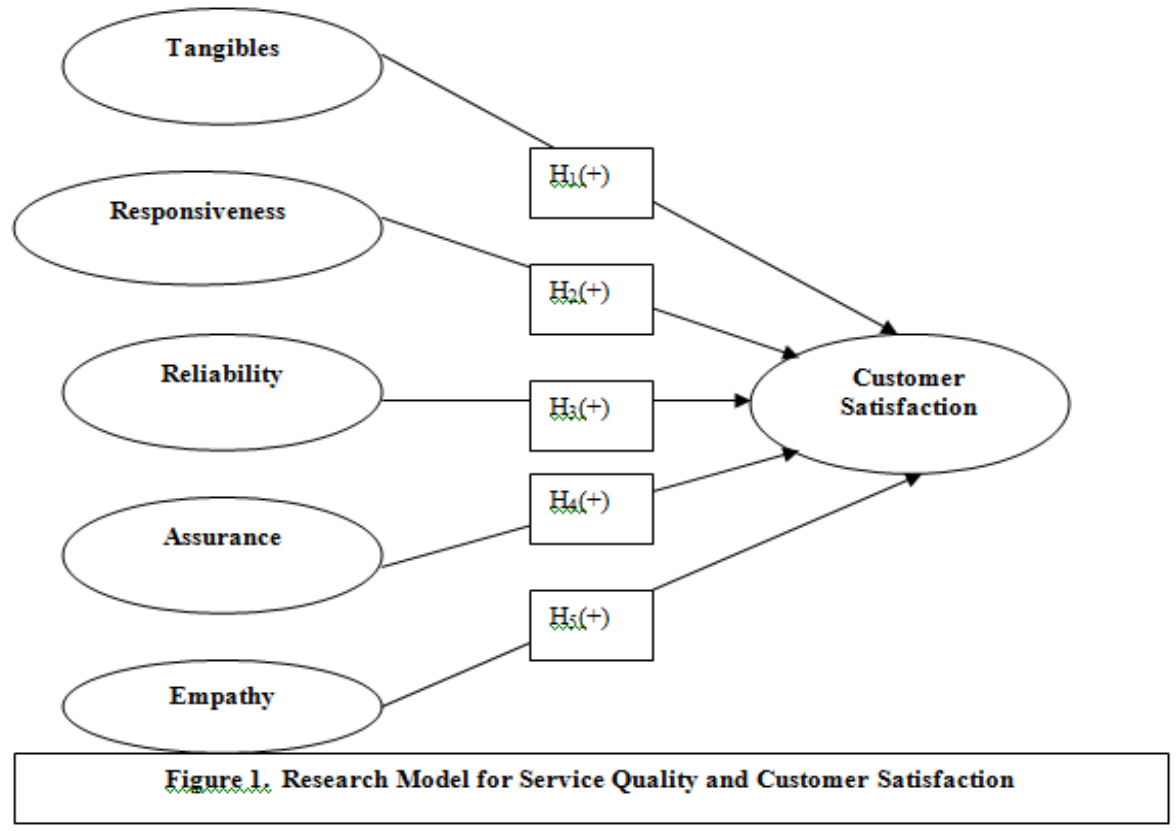

The hypotheses are:

$\mathrm{H}_{1}$ : There is a positive correlation between tangibles and customer satisfaction in new private sector banks in Chennai.

$\mathrm{H}_{2}$ : There is a positive correlation between responsiveness and customer satisfaction in new private sector banks in Chennai.

$\mathrm{H}_{3}$ : There is a positive correlation between reliability and customer satisfaction in new private sector banks in Chennai.

$\mathrm{H}_{4}$ : There is a positive correlation between assurance and customer satisfaction in new private sector banks in Chennai.

$\mathrm{H}_{5}$ : There is a positive correlation between empathy and customer satisfaction in new private sector banks in Chennai.

\section{Methodology}

Among the different cities in Tamil Nadu, the Chennai city has been purposively selected followed by new private sector banks and customers for the present study. The 400 customers of Axis bank, HDFC bank, ICICI bank and Yes bank have been selected for the present study by adopting multi stage random sampling technique and the data and information pertain to the year 2011-2012. The service quality is assessed based on Parasuraman, et. al.,'s (1988) five dimensions namely, tangibility, reliability, responsiveness, assurance and empathy. All questions are measured on 5-point likert scale where " $1=$ strongly disagree", " $2=$ disagree", " $3=$ neutral", " $4=$ agree", and " $5=$ strongly agree".

The overall customer satisfaction is measured by one item question: "Overall, how satisfied are you with the bank?" The responses are made on scale labelled "very satisfied" and "very dissatisfied" at both extremes. The problems associated with the use of a single response variable are moderated by the simplicity of the question and Yi's (1990) suggestion that a single overall satisfaction measure scored as this one was is "reasonably valid". In order to accomplish the objectives, the descriptive statistics, correlation analysis and multiple regression have been applied.

\subsection{Socio-Economic Characteristics of Customer}

\section{Results And Discussion}

The socio-economic characteristics of customers of new private sector banks were analysed and the results are presented in Table-1. The results show that about 64.25 per cent of the customers are males and the rest of 35.75 per cent of the customers are females. The results indicate that about 46.25 per cent of the customers belong to the age group of 30-40 years followed by 20-30 years (24.50 per cent), 40-50 years (17.75 per cent) and 50-60 years (11.50 per cent). It is clear that the majority of the customers ( 33.50 per cent) are post 
graduates followed by professionals (26.50 per cent), graduates ( 25.50 per cent) and higher secondary (14.50 per cent).

It is apparent that about 39.50 per cent of the customers are salaried followed by self-employed ( 23.50 per cent), professional ( 21.50 per cent) and business ( 15.50 per cent). It is observed that about 41.00 per cent of the customers belong to the monthly income group of Rs.20000-30000 followed by Rs. 30000-40000(27.50 per cent), Rs. 10000-20000(18.00 per cent) and Rs. 40000-50000(13.50 per cent).

Table-1. Socio-Economic Characteristics of Customer

\begin{tabular}{|c|c|c|}
\hline Particulars & Frequency & Per cent \\
\hline \multicolumn{3}{|l|}{ Gender } \\
\hline Male & 257 & 64.25 \\
\hline Female & 143 & 35.75 \\
\hline \multicolumn{3}{|l|}{ Age( Years) } \\
\hline $20-30$ & 98 & 24.50 \\
\hline $30-40$ & 185 & 46.25 \\
\hline $40-50$ & 71 & 17.75 \\
\hline $50-60$ & 46 & 11.50 \\
\hline \multicolumn{3}{|c|}{ Educational Qualification } \\
\hline Higher Secondary & 58 & 14.50 \\
\hline Graduates & 102 & 25.50 \\
\hline Post Graduates & 134 & 33.50 \\
\hline Professionals & 106 & 26.50 \\
\hline \multicolumn{3}{|l|}{ Occupation } \\
\hline Business & 62 & 15.50 \\
\hline Self-Employed & 94 & 23.50 \\
\hline Salaried & 158 & 39.50 \\
\hline Professional & 86 & 21.50 \\
\hline \multicolumn{3}{|l|}{ Monthly Income(Rs.) } \\
\hline $10000-20000$ & 72 & 18.00 \\
\hline $20000-30000$ & 164 & 41.00 \\
\hline $30000-40000$ & 110 & 27.50 \\
\hline $40000-50000$ & 54 & 13.50 \\
\hline
\end{tabular}

\subsection{Service Quality Dimensions and Reliability}

The descriptive statistics of mean and standard deviation of service quality dimensions and overall satisfaction of customers were worked out and the results are presented in Table-2. The customers of new private sector banks perceive responsiveness $(\mathrm{M}=3.82)$ is to be the most dominant service quality followed by reliability $(\mathrm{M}=3.80)$, tangibles $(\mathrm{M}=3.74)$, assurance $(\mathrm{M}=3.72)$ and empathy (3.68) in the order of importance based on the mean values of each service quality dimension. Meanwhile, the most of the customers are highly satisfied with the service quality of new private sector banks.

Table-2 Mean and Standard Deviation of Service Quality and Overall Satisfaction of Customers

\begin{tabular}{|l|c|c|c|}
\hline \multicolumn{1}{|c|}{ Particulars } & Mean & Standard Deviation & Reliability-Cronbach's Alpha \\
\hline Tangibles & 3.74 & 0.85 & 0.86 \\
\hline Responsiveness & 3.82 & 0.84 & 0.83 \\
\hline Reliability & 3.80 & 0.78 & 0.85 \\
\hline Assurance & 3.72 & 0.82 & 0.81 \\
\hline Empathy Customer & 3.68 & 0.72 & 0.84 \\
\hline $\begin{array}{l}\text { Overall } \\
\text { Satisfaction }\end{array}$ & 4.78 & 0.74 & 0.78 \\
\hline
\end{tabular}

Using Cronbach's coefficient, internal consistency for service quality dimensions and overall customer satisfaction was estimated as 0.86 for tangibles dimension, 0.83 for responsiveness dimension, 0.85 for reliability dimension, 0.81 for assurance dimension, 0.84 for empathy dimensions and 0.78 for overall customer satisfaction. Usually a reliability coefficient above 0.70 is considered sufficient for exploratory studies (Nunnally, 1967). The reliability values are all above 0.80 . Thus, it can be concluded that the measures used in the present study are valid and reliable. 


\subsection{Relationship between Service Quality Dimensions and Customer Satisfaction}

The relationship between service quality dimensions and customer satisfaction was analysed by computing correlation coefficient and the results are presented in Table-3. The correlation analysis shows that the service quality dimensions are positively and moderately associated with overall customer satisfaction.

Table-3. Relationship between Service Quality Dimensions and Customer Satisfaction

\begin{tabular}{|l|c|c|c|c|c|c|}
\hline & Tangibles & Responsiveness & Reliability & Assurance & Empathy & $\begin{array}{c}\text { Customer } \\
\text { Satisfaction }\end{array}$ \\
\hline Tangibles & $\mathbf{1 . 0 0}$ & & & & & \\
\hline Responsiveness & $0.52^{* *}$ & $\mathbf{1 . 0 0}$ & & & & \\
\hline Reliability & $0.68^{* *}$ & $0.53^{* *}$ & $\mathbf{1 . 0 0}$ & & & \\
\hline Assurance & $0.59^{* *}$ & $0.47^{* *}$ & $0.43^{* *}$ & $\mathbf{1 . 0 0}$ & & \\
\hline Empathy & $0.62^{* * *}$ & $0.42^{* *}$ & $0.57^{* *}$ & 0.55 & $\mathbf{1 . 0 0}$ & \\
\hline $\begin{array}{l}\text { Customer } \\
\text { Satisfaction }\end{array}$ & $0.58^{* *}$ & $0.66^{* *}$ & $0.63^{* *}$ & $0.61^{* *}$ & $0.42^{* *}$ & $\mathbf{1 . 0 0}$ \\
\hline
\end{tabular}

Note: ${ }^{* *}$ indicates significant at one per cent level.

The results further reveal that there is a significant and positive relationship between five dimensions of service quality and customer satisfaction, the highest correlation is between responsiveness and customer satisfaction $(\mathrm{r}=0.66 ; \mathrm{p}<0.01)$ followed by between reliability and customer satisfaction $(\mathrm{r}=0.63 ; \mathrm{p}<0.01)$ between assurance and customer satisfaction $(\mathrm{r}=0.61 ; \mathrm{p}<0.01)$ and between tangibles and customer satisfaction $(\mathrm{r}=0.58 ; \mathrm{p}<0.01)$. The weakest association is between empathy and customer satisfaction $(r=0.42 ; \mathrm{p}<0.01)$. The results indicate that the most important service quality practice on customer satisfaction is responsiveness (i.e.. with the highest value of correlation co-efficient) which proves that responsiveness is perceived as a dominant service quality. Thus, the null hypotheses of this study are supported.

\subsection{Influence of Service Quality Dimensions on Overall Customer Satisfaction}

The influence of service quality dimensions on overall customer satisfaction was analysed by employing multiple regression and the results are presented in Table-4. The results indicate that the coefficient of multiple determination $\left(\mathrm{R}^{2}\right)$ is 0.66 and adjusted $\mathrm{R}^{2}$ is 0.63 indicating the regression model is reasonably fit. It is inferred that about 63.00 per cent of the variation in dependent variable (Overall Customer Satisfaction) is explained by the independent variables (Service Quality Dimensions).

Table-4. Influence of Service Quality Dimensions on Overall Customer Satisfaction

\begin{tabular}{|l|c|c|c|}
\hline \multicolumn{1}{|c|}{ Variable } & Regression Co-efficient(Beta) & t-value & Sig \\
\hline Constant & $-0.219^{* * *}$ & 4.428 & 0.00 \\
\hline Tangibles & $0.106^{* *}$ & 3.224 & 0.01 \\
\hline Responsiveness & $0.164^{* * *}$ & 3.862 & 0.00 \\
\hline Reliability & $0.145^{* *}$ & 3.546 & 0.00 \\
\hline Assurance & $0.132^{* *}$ & 3.310 & 0.01 \\
\hline Empathy & $-0.098^{* *}$ & 2.982 & 0.01 \\
\hline $\mathrm{R}^{2}$ & 0.658 & & \\
\hline Adjusted $\mathrm{R}^{2}$ & 0.634 & & \\
\hline $\mathrm{F}$ & 27.621 & & 0.00 \\
\hline $\mathrm{N}$ & 400 & & \\
\hline
\end{tabular}

Note: ${ }^{*}$ indicates significant at one per cent level.

The proposed model is adequate as the F-statistic $=27.621$ and it is significant at one per cent level $(\mathrm{p}$ $<0.01)$. This indicates that there is a statistically significant association between service quality dimensions and overall customer satisfaction. The results show that the service quality dimensions of tangibles, responsiveness, reliability and assurance are positively and significantly influencing the customers overall satisfaction, while the empathy is negatively and significantly influencing the customers overall satisfaction at one per cent level in new private sector banks. Thus, it indicates that there is a statistically significant link between service quality dimensions and overall customer satisfaction. 


\section{Conclusion}

The main objective of this study is to examine the influence of service quality dimensions on customer overall satisfaction. This study posits and develops an instrument of service quality and examines the relationship between perceived service quality dimensions and customer overall satisfaction. The research model proposed in the study postulates that service quality dimensions influence on overall customer satisfaction directly. The model also postulates that service quality has a positive relationship with overall customer satisfaction and tested them through Correlation Analysis and Multiple Regression to find their significance in the hypotheses.

The results shows that the most important service quality practice on customer satisfaction is responsiveness as it is perceived as a dominant service quality. The results reveal that the service quality dimensions of tangibles, responsiveness, reliability and assurance are positively and significantly influencing the customers overall satisfaction, while the empathy is negatively and significantly influencing the customers overall satisfaction. Thus, this present research concluded that service quality is the basic and also most important factor that influences the overall customer satisfaction. This finding reinforces the need for banks managers to place an emphasis on the underlying dimensions of service quality especially on responsiveness and should start with improving service quality in order to raise overall customer satisfaction.

Further, this study is consistent with those of prior research in concluding that: service quality is a significant influencer of overall customer satisfaction, and service quality dimensions are the basic factors that affect overall customer satisfaction. It is apparent that focusing on delivering high quality services and improve service quality effectively is critical for customer satisfaction. In addition, the satisfaction of customers was significantly influenced by the (Tangibles, Responsiveness, Reliability and assurance). It is thus apparent that managers of new private sector banks could make assessing and monitoring service quality in banks periodically, to enable the banks to identify where improvements are needed from the customers' viewpoint and to place an emphasis on the underlying dimensions of service quality, especially on responsiveness and should start with improving service quality in order to raise overall customer satisfaction.

\section{References}

[1] Abdullah, Shabib., (2002). Measuring Customer Satisfaction for Business Services Quality to Islamic Financial Institutions in Kuwait. Unpublished Master Thesis, Faculty of Commerce, Shams University.

[2] Ahmed, I., Nawaz, M., Usman, A., Shaukat, M., Ahmad, N., and Iqbal, H., (2010). Impact of Service Quality on Customers' Satisfaction: Empirical Evidence from Telecom Sector of Pakistan. Interdisciplinary Journal of Contemporary Research in Business, 1(12): $98-113$

[3] Al-Hawari, M. and Ward, T., (2006). The Effect of Automated Service Quality on Australian Banks' Financial Performance and The Mediating Role of Customer Satisfaction. Marketing Intelligence \& Planning, 24(2): 127-147.

[4] Anber Abraheem Shlash Mohammad and Shireen Yaseen Mohammad Alhamadani(2011). Service Quality Perspectives and Customer Satisfaction in Commercial Banks Working in Jordan. Middle Eastern Finance and Economics, 14(1):.60-72.

[5] Angur, Madhukar G., Nataraajan, Rajan and Jahera Jr, John S., (1999). Service Quality in the Banking Industry: An Assessment in A Developing Economy. International Journal of Bank Marketing, 17 (3):116-123.

[6] Babakus, E., and Boller, G., (1992). An Empirical Assessment of the SERVQUAL Scale. Journal of Business Research, 24(3): 253

[7] Babakus, E., and Yavas, U., (2008). Does Customer Sex Influence the Relationship Between Perceived Quality and Share of Wallet?. Journal of Business Research, 61(9): 974-981.

[8] Bahia, K., and Nantel, J.,(2000). A Reliable and Valid Measurement Scale for the Perceived Service Quality of Banks. The International Journal of Bank Marketing, 18(2):84.

[9] Baker, D. A., and Crompton, J. L.,(2000). Quality Satisfaction and Behavioral Intentions. Annals of Tourism Research, 27 (3): $785-$ 804.

[10] Beer, Michael,(2003). Why Total Quality Management Programs Do not Persist the Role of Management Quality and Implication for Leading a TQM Transformation. Decision Science, 34(4): 624-642.

[11] Beerli, A., Martin, J. D., and Quintana, A., (2004). A Model of Customer Loyalty in the Retail Banking Market. European Journal of Marketing, 38(1/2):253-275.

[12] Bei, L.T., and Chiao, Y.C. (2006). The Determinants of Customer Loyalty: An Analysis of Intangible Factors in Three Service Industries. International Journal of Commerce and Management, 16 (3/4):162-177.

[13] Carman, J.M., (1990). Consumer Perceptions of Service Quality: An Sssessment of the SERVQUAL Dimensions. Journal of Retailing, 66 (1): 33-55.

[14] Chaniotakis, I., and Lymperopoulos, C., (2009). Service Quality Effect on Satisfaction and Word-Of-Mouth in the Healthcare Industry. Managing Service Quality, 19(2): 229-242.

[15] Cronin, J. and Taylor, S. (1992). Measuring Service Quality: A Re-examination and Extension. Journal of Marketing,56(3): 55-68.

[16 ]Devlin, J., (2001). Consumer Evaluation And Competitive Advantage In Retail Financial Services: A Research Agenda. European Journal of Marketing, 35(5/6): 639-660.

[17] Gilbert, G.R., Veloutsou, C., Goode, M.M.H. and Moutinho, L., (2004). Measuring Customer Satisfaction in the Fast Food Industry: A Cross-National Approach. The Journal of Services Marketing, 18 (5): 371-383.

[18] Huang, M. C., (1998). An Empirical Study on the Model of Relationship Value-Loyalty for the Banking Industry. Master Dissertation, National YunLin University of Science \& Technology, Yunlin, Taiwan.

[19] Huseyin Arasli, Salime-Smachi and Salih Turan Katircioglu,(2005).Customer Service Quality in the Derek Cypriot Banking Industry. Managing Service Quality, 15(1): 41-56.

[20] Ibanez V.A., Hartmann P., and Calvo P.Z.(2006). Antecedents of Customer Loyalty in Residential Energy Markets: Service Quality, Satisfaction, Trust and Switching Costs. The Service Industries Journal, 26(6): 633-650. 
[21] Jamal, A., and Naser, K., (2003). Factors Influencing Customer Satisfaction in the Retail Banking Sector in Pakistan. International Journal of Commerce and Management, 13(2):29-53.

[22] Karatepe, O., Yavas, U., and Babakus, E., (2005). Measuring Service Quality of Banks: Scale Development and Validation. Journal of Retailing and Consumer Services, 12(5): 373-383.

[23] Karim newrian and Alan Cowling.,(1996). Service Quality Banking: The Experience of Tow British Clearing Banks. International Journal of Bank Marketing, 14(6): 3-15.

[24] Kotler, P., (2003). Marketing Management. $11^{\text {th }}$ ed., Prentice-Hall, Englewood Cliffs, New Jersey.

[25] Kotler, P. and Armstrong, G., (1999). Principles of Marketing, $8^{\text {th }}$ ed., Prentice-Hall, Englewood Cliffs, New Jersey.

[26] Kumar, S. A., Mani, B. T., Mahalingam, S., and Vanjikovan, M., (2010). Influence of Service Quality on Attitudinal Loyalty in Private Retail Banking: An Empirical Study. IUP Journal of Management Research, 9(4): 21-38.

[27] Lanka, U., Suar, D., and Mohapatara, P.K.J., (2009). Service Quality, Customer Satisfaction and Customer Loyalty In Indian Commercial Banks. The Journal of Entrepreneur, 18(1): 47-64.

[28] Levesque, T. and McDougall, G.H.G. (1996). Determinants of Customer Satisfaction in Retail Banking. International Journal of Bank Marketing, 14(7): 12-20.

[29] Mengi, P., (2009). Customer Satisfaction with Service Quality: An Empirical Study of Public and Private Sector Banks. IUP Journal of Management Research, 8(9):7-17.

[30] Mohamed Hossain and Shirley Leo.,(2009). Customer Perception on Service in Middle East: The Case of Qatar. International Journal of Islamic and Middle Easterm Finance and Management, 2(4): 338-350.

[31] Mosahab, R.; Mahamad, O. and Ramayah, T., (2010). Service Quality, Customer Satisfaction And Loyalty: A Test o Mediation. International Journal of Business and Management,3(4): 80-85.

[32] Mualla and Naje Deeb, (1998). Measuring Banking Service Quality Provided by Jordanian Commercial Banks : A Field Study. Derassat for Administrative Science, 25(2): 335-357.

[33] Muhammad Ehsan Malik, Basharat Naeem and Zoune Arif (2011). How Do Service Quality Perceptions Contribute in Satisfying Banking Customers?. Interdisciplinary Journal of Contemporary Research in Business, 3(8): 646-653.

[34] Nunnally, J., (1967). Psychometric Theory. McGraw-Hill, Inc., New York.

[35] Oliver, R.L., (1997). Satisfaction: A Behavioral Perspective on the Consumer. McGraw Hill, New York.

[36] Parasuraman, A. Berry, L. and Zeithaml, V.A, (1985). A Conceptual Model of Service Quality and Its Implication for Future Research. Journal of Marketing,49(4): 41-50.

[37] Parasuraman, A . Berry, L. and Zeithaml, V.A., (1988). SERVQUAL: A Multiple-Item Scale for Measuring Consumer Perceptions of Service Quality. Journal of Retailing, 64(1): 12-40.

[38] Parasuraman, A., Berry, L.L. and Zeithaml, V.A., (1991). Understanding Customer Expectations of Service. Sloan Management Review,32 (3): 39-48.

[39] Shemwell, D. J., Yava,Ș, U., and Bilgin, Z.,(1998). Customer-Service Provider Relationship: An Empirical Test of a Model of Service Quality, Satisfaction and Relationship Oriented Outcome. International Journal of Service Industry Management, 9(2): 155168.

[40] Wirtz, J., Mattila, A. S., and Tan, R. L., (2000). The Moderating Role of Target-Arousal on the Impact of Affect in Satisfaction-An Examination in the Context of Service Experiences. Journal of Retailing, 76(3): 347-365.

[41] Yi, Y. ,(1990). A Critical Review of Consumer Satisfaction. In Zeithaml, V.A, ed., Review of Marketing” American Marketing Association, 68-123.

[42] Zeithaml, V. A., (1987). Defining and Relating Price, Perceived Quality, and Perceived Value'. Report No. 87-101, Marketing Science Institute, Cambridge, MA.

[43] Zeithaml, V.A. and Bitner, M.J., (2000). Services Marketing. McGraw-Hill, New York.

[44] Zeithaml, V. A., and Bitner, Mary Jo., (2003). Services Marketing: Integrating Customer Focus across the Firms. $3^{\text {rd }}$ Edition, TataMçGraw Hill, New Delhi. 